\title{
Effect of Herbicides Used in Horticulture (2,4-D, Glyphosate and Nicosulfuron) on Snails Achatina fulica (Bowdich, 1720)
}

\author{
Aya Elichama Désirée Phaceli1 ${ }^{*}$, Mama koné1 ${ }^{1}$ Ardjouma Dembele², \\ Jean Florent $\mathrm{Haba}^{3}$, Emile Kouadio Yao ${ }^{2}$
}

${ }^{1}$ Laboratoire de physiologie, de pharmacologie et de pharmacopée, UFR des Sciences de la Nature, Université Nangui Abrogoua, Abidjan, Côte d'Ivoire

${ }^{2}$ Laboratoire National d'Appui au Développement Agricole (LANADA), Abidjan, Côte d'Ivoire

${ }^{3}$ Laboratoire de biodiversité et de gestion durable des écosystèmes, UFR des Sciences de la Nature, Université Nangui Abrogoua, Abidjan, Côte d'Ivoire

Email: *phade96@gmail.com

How to cite this paper: Phaceli, A.E.D. koné, M., Dembele, A., Haba, J.F. and Yao, E.K. (2021) Effect of Herbicides Used in Horticulture (2,4-D, Glyphosate and Nicosulfuron) on Snails Achatina fulica (Bowdich, 1720). Journal of Agricultural Chemistry and Environment, 10, 402-414.

https://doi.org/10.4236/jacen.2021.104026

Received: May 17, 2021

Accepted: September 25, 2021

Published: September 28, 2021

Copyright $\odot 2021$ by author(s) and Scientific Research Publishing Inc. This work is licensed under the Creative Commons Attribution International License (CC BY 4.0).

http://creativecommons.org/licenses/by/4.0/

\begin{abstract}
2,4-Dichlorophenoxyacetic (2,4-D), glyphosate, and nicosulfuron, because of their modes of action and selectivity, are the most widely used herbicides in Ivorian horticulture. Fuels toxicity was the reason of many debates in the world because of their massive and uncontrolled use. They are frequently blamed for the reduction of soil fertility and terrestrial biodiversity observed in agricultural areas. In view of the debates raised by their toxicities, the use of these herbicides requires the greatest caution and clear information on the real risk incurred by the edaphic fauna by conducting ecotoxicity studies. The present study aims to evaluate the effect of 2,4-D, glyphosate and nicosulfuron herbicides on the growth and reproduction of Achatina fulica snails in microcosm. To do this, we treated each plot on which snail microcosms were placed with 2,4-D, glyphosate or nicosulfuron herbicides according to the manufacturer's recommendations. The results showed for all the herbicides used, that after 28 days of exposure, the growth of juvenile snails was slowed down. The number of eggs laid per pair was reduced in adult snails. The egg hatchability test revealed a reduction in egg hatchability. In addition, each effect was dependent on the herbicide used. Thus, toxicity was found to be greater according to the following order: nicosulfuron $<$ glyphosate $<2,4$-D. From the results obtained, we concluded that 2,4-D, glyphosate, and nicosulfuron treatments under field conditions are a potential threat to the sustainability of snail species and therefore to soil life. The intensity of the effect depends on the toxicity of the herbicides used.
\end{abstract}




\section{Keywords}

Herbicide Effect, Growth, Reproduction, Achatina fulica, Microcosm

\section{Introduction}

The modernization of agriculture through the adoption of new crop production techniques is one of the solutions to the problems of food insufficiency. These problems are linked to the galloping growth of the world's population, which increased from 3 to 7 billion people between 1960 and 2011 [1]. The magnitude of this population growth has resulted in the depletion of available resources. Aware of the consequences of this, many organizations such as the FAO have implemented several strategies since 1947 in order to increase agricultural production [2]. These strategies were largely based on encouraging farmers to use fertilizers, farm machinery and pesticides to increase their [3]. Years later, the benefits were felt. The only thing that was talked about was the effectiveness of pesticides on target species. Since then, the use of these plant protection products was considered a prerequisite for successful agricultural production [4].

As part of this agricultural development trend, Côte d'Ivoire has been using modern crop protection methods based on the use of phytosanitary products for several decades. Of the large family of pesticides, herbicides represent to date, the most used phytosanitary product in agriculture. In Côte d'Ivoire, for the year 2016 alone, the quantity of pesticides imported is estimated at 20,000 tons, two-thirds of which were herbicides [5]. Their massive uses are justified by the fact that they reduce the cost of labor and mitigate the ardor of work [6]. 63.64\% of imported herbicides are for horticulture [7]. According to [7] the most used are glyphosate and nicosulfuron. Yet horticulturists use glyphosate in combination with 2,4-Dichlorophenoxyacetic (2,4-D). They accounted for $41.04 \%$ of the herbicides registered by the Ivorian government in 2012 [8]. Notwithstanding their advantages, the recurrent and often uncontrolled use of these herbicides is subject to sharp criticism due to their environmental effects [9]. In many cases, studies have shown that the amount of herbicide that comes into contact with target organisms during plant protection treatments is minimal. It is estimated at $0.3 \%$ against $97.7 \%$ of the treatment discharged into the environment [10].

It seems therefore important, even primordial to carry out studies, in order to know the impact of these herbicides in the various compartments of the environment mainly the soil, the first environmental receiver of the drifts of herbicides. Among the animals that can be used as bioindicators to assess soil contamination, snails are the most suitable [11]. They live at the soil-plant-air interface and are a component of the soil fauna. They are primary consumers and decomposers [12]. Previous studies have been conducted in an effort to learn the impact of pesticides on the growth of juvenile snails [13] [14]. Most of these studies have been largely conducted in the laboratory, away from environmental conditions. 
Yet environmental factors influence the behavior of herbicides during plant protection treatments [15]. The objective of this study was to evaluate the effect of 2,4-D, glyphosate, and nicosulfuron on snail growth and reproduction in situ.

\section{Materials and Methods}

\subsection{Study Area}

This study was conducted in the village of Abbè Bégnini in the commune of Azaguié (Figure 1). The commune of Azaguié is located in the southeast of Côte d'Ivoire, about $40 \mathrm{~km}$ north of Abidjan, between latitudes $5^{\circ} 35$ and $6^{\circ} 15$ north and longitudes $3^{\circ} 55$ and $4^{\circ} 40$ west. It belongs to the forest zone and to the humid tropical climate of the Atenean type. Most of the soils in this locality belong to the ferralitic soil class [16]. In addition, Azaguié is a horticultural area, so
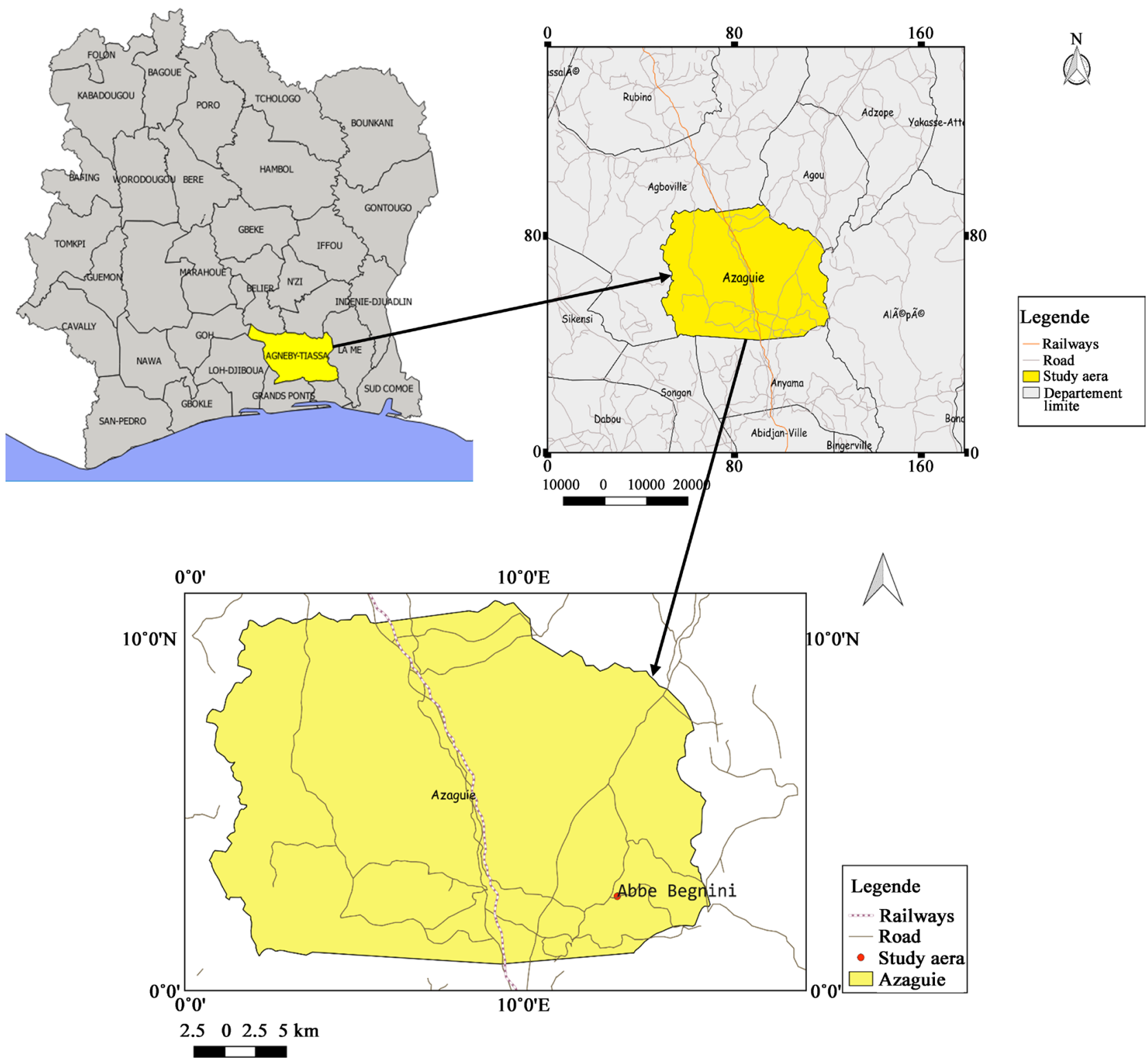

Figure 1. Study area. 
it provides the best information on the impact of herbicides used in horticulture.

\subsection{Materials}

\subsubsection{Biological Materials}

The biological material consisted of animal and plant biological material.

- The animal biological material consisted of adult snails of the species Achatina fulica whose average snail mass, length and average shell diameter were $138 \pm$ $10 \mathrm{~g}, 14 \pm 2.4 \mathrm{~cm}$ and $11 \pm 1.5 \mathrm{~cm}$ respectively.

- The plant material was mainly used for feeding snails. It consisted of leaves and fruits of papaya (Carica papaya).

\subsubsection{Herbicide Products}

Three herbicides were used in this study. They are:

- Glycel 410 SL from the firm Topex Agro-élevage Développement SARL. The active ingredient was glyphosate at $410 \mathrm{~g}$ ( $41 \%$ isopropilamine salt) per liter of commercial solution. To achieve the desired effect, the manufacturer recommended diluting $200 \mathrm{~mL}$ of product in $15 \mathrm{~L}$ of water per $1 / 2$ hectare of land. This rate corresponded to a solution of $5.47 \mathrm{~g} / \mathrm{L}$.

- Extra 720 SL from Crop Doctor. The active ingredient was 2,4-D formulated as a soluble liquid (SL) at $720 \mathrm{~g}$ (amine salt) per liter of commercial solution. The manufacturer recommended the use of $40 \mathrm{~mL}$ to $50 \mathrm{~mL}$ for a $16 \mathrm{~L}$ water sprayer. These dosages corresponded to solutions of $1.8 \mathrm{~g} / \mathrm{L}$ to $2.5 \mathrm{~g} / \mathrm{L}$ respectively.

- Sofa 40 SC distributed by the firm AF-CHEM SOFACO. The active ingredient was nicosulfuron. The formulation used was a suspension concentrate (SC) with $40 \mathrm{~g}$ of nicosulfuron per liter of commercial solution. The manufacturer recommended diluting $1 \mathrm{~L}$ of the product in $60 \mathrm{~L}$ to $200 \mathrm{~L}$ of water to treat 1 ha. These rates were $0.66 \mathrm{~g} / \mathrm{L}$ to $0.2 \mathrm{~g} / \mathrm{L}$.

\subsection{Methods}

\subsubsection{Breeding of Snails Achatina fulica}

The purpose of this operation was to standardize the age of the snails and to have a large number of individuals available for ecotoxicological tests.

\section{1) Collection of broodstock}

Adult snails of the species Achatina fulica intended for breeding were obtained from the local market. They were weighed and then transferred to tanks for breeding. The criteria for their selection were essentially morphological. The average weight mass of the snails, the length and the average diameter of the shell were respectively $138 \pm 10 \mathrm{~g}, 14 \pm 2.4 \mathrm{~cm}$ and $11 \pm 1.5 \mathrm{~cm}$. The breeding was carried out in the laboratory.

\section{2) Management of the breeding}

The breeders were distributed in five breeding tanks at a rate of 12 animals per tank. Each tank was labelled according to the weight mass of the individuals. The snails were fed every two days with leaves and fruits of papaya at a rate of $10 \mathrm{~g}$ 
for the leaves and $50 \mathrm{~g}$ for the fruits, that is to say $60 \mathrm{~g}$ of food per tank. The decomposed wood, previously dried and crushed, was used as litter. The thickness of the litter was $10 \mathrm{~cm}$. To humidify the environment, $500 \mathrm{~mL}$ of fountain water was added. The bedding was changed twice a week. The bins were inspected daily between 9 and 10 am to remove waste from the the environment and to recover eggs in case of egg laying.

The eggs obtained in the bins were then transferred to plastic boxes. The boxes were 30 in number. Each of these boxes contained $200 \mathrm{~g}$ of dried and ground decaying wood and 50 broodstock eggs. The whole was moistened with $50 \mathrm{~mL}$ of fountain water. A total of 30 environments were prepared. After about two weeks of incubation, the eggs hatched. Two (2) g of papaya leaves were placed in the environment after the eggs hatched to serve as food for the spat. The food was renewed every two days. The four-week-old spat were placed on environment of the same composition as the rearing environment at a rate of 20 individuals per tank. Ecotoxicological tests were carried out on this second generation of Achatina fulica individuals. The culture environment was prepared in plastic tanks of dimensions $42 \mathrm{~cm} \times 32 \mathrm{~cm} \times 22 \mathrm{~cm}$.

\subsubsection{Determination of the Effects of 2,4-D, Glyphosate and Nicosulfuron} Herbicides on the Growth of Juvenile Achatina fulica Snails

The test protocol was inspired by the ISO 15952 standard on the effects of pollutants on juvenile snails (Helicidae) and the determination of effects on growth by soil contamination and then by the guideline No. 243 for testing chemicals, developed by the Organization for Economic Cooperation and Development [17] [18].

\section{1) Preparation of the microcosms}

The experimental plot was subdivided into four elementary plots $5 \mathrm{~m}$ apart. The area of each elementary plot was $1350 \mathrm{~m}^{2}$. These plots were not previously treated with herbicides. $24 \mathrm{~h}$ before the beginning of the test, 5 microcosms were prepared and placed on each elementary plot.

They were each made up of circular frames of $22 \mathrm{~cm} \times 10 \mathrm{~cm}$ sunk to a depth of $5 \mathrm{~cm}$ in the soil so that they were firmly attached. Three juveniles of the species Achatina fulica were placed in each microcosm. Before the start of the test, measurements of the snails were taken. The length, shell diameter and mass of the snails were $3 \pm 0.5 \mathrm{~cm} ; 1.8 \pm 0.4 \mathrm{~cm} ; 5 \pm 1 \mathrm{~g}$ respectively. A quantity of $50 \mathrm{~g}$ of food was deposited every three days in each environment, i.e. $10 \mathrm{~g}$ of leaves and $40 \mathrm{~g}$ of papaya fruits. The experimental units were then covered with a mosquito net to prevent the escape of snails and the intrusion of other organisms. Wooden stakes were used to hold the nets to the ground. A total of 20 microcosms were used throughout the experimental plot. The test was conducted in undergrowth, a preferred environment for snail development.

\section{2) Herbicide treatments of the experimental plot}

Each elemental plot underwent a single herbicide treatment of 2,4-D, glyphosate or nicosulfuron at concentrations recommended by the manufacturer. The 
solutions were prepared with fountain water. Another elementary plot close to the previous ones is used as a negative control.

Some pawpaw trees at the study site were treated with 2,4-D, glyphosate, or nicosulfuron at the beginning of the test, at a rate of one pawpaw per herbicide. The leaves and fruit of these pawpaws were used as food for the snails during the test. The first foods deposited in the microcosms were not pre-treated. They were treated at the same time as the experimental plot. Another untreated papaya tree was used as food for the control snails.

The snails stayed in the environment for 28 days. Snail mass, length and shell diameter were measured weekly. Each snail was weighed individually. The length and diameter of the shell were measured with a caliper. The growth of exposed and control individuals was calculated from the increase in length, diameter and weight mass of the snail from the beginning to the end of the test. During the exposure to the different treatments, the more or less disturbed behaviors of the snails were described.

\subsubsection{Determination of the Effects of 2,4-D, Glyphosate and Nicosulfuron Herbicides on the Reproduction of Achatina fulica Snails}

The effect of 2,4-D, glyphosate and nicosulfuron herbicides on reproduction, is assessed by the number of eggs laid and the hatching rate, using the guideline No. 243 for chemical testing, developed by the Organization for Economic Cooperation and Development [18].

\section{1) Effect on egg production of Achatina fulica snails}

The test to evaluate the effects of 2,4-D, glyphosate, and nicosulfuron on snail reproduction follows the same procedure as the previous test on growth. The only differences are in the number and age of individuals used per microcosm. Two individuals of 5 months of age from the farm and weighing $130 \pm 3 \mathrm{~g}$ were placed in each experimental unit. Eggs were counted per week in each experimental chamber.

\section{2) Effect on the hatching rate of Achatina fulica snails}

The experimental unit was a $500 \mathrm{~mL}$ transparent plastic box. These boxes contained $200 \mathrm{~g}$ of decomposed wood litter previously crushed and dried, to which were added 50 eggs of Achatina fulica from the breeding environments. $24 \mathrm{~h}$ after oviposition, the microcosms were buried in holes whose bottom was lined with stones to ensure efficient water drainage and so that the level of the boxes was $2 \mathrm{~cm}$ above the surrounding soil. The microcosms were humidified with $50 \mathrm{~mL}$ of fountain water to bring the temperature of the environment to $26^{\circ} \mathrm{C} \pm 1^{\circ} \mathrm{C}$ which is the optimal temperature for egg incubation. The lid of the boxes was also perforated to allow good aeration of the environment. Note that this study was conducted at the same time as the study of the effects of 2,4-D, glyphosate, and nicosulfuron on the growth and reproduction of juvenile Achatina fulica snails. Microcosms for both tests were arranged horizontally at a distance of $1 \mathrm{~m}$ from each other. 10 microcosms were used for this test and placed on each elementary plot. These plots were treated with a single type of herbicide, 
either 2,4-D, glyphosate or nicosulfuron. Another plot close to the previous ones served as a negative control. The environment was visited every five days. The hatching rate was determined by the following equation:

$$
\operatorname{HR}(\%)=\frac{\mathrm{NEH} \times 100}{\mathrm{TNE}}
$$

where:

HR (\%): hatching rate;

NEH: number of eggs hatched;

TNE: total number of eggs put in culture.

\subsection{Statistical Analysis}

In this study, the data were analyzed with the software statistica 7.1. Data obtained on the effects of 2,4-D, glyphosate, and nicosulfuron on the growth and egg production of Achatina fulica snails were subjected to a one-factor analysis of variance. If there was a significant difference, means were separated into homogeneous groups using Tukey's HSD test at the $5 \%$ threshold. The non-parametric Kruskall Wallis test was used to analyze the hatchability data of Achatina fulica eggs. The means obtained were then separated into homogeneous groups with the Tukey HSD test at the $5 \%$ threshold.

\section{Results and Discussion}

\subsection{Results}

\subsubsection{Behavioral Effects of Snails during the Test}

Some behaviors due to the exposure of snails to herbicides could be observed during this study. These are: the ability of snails to feed normally or avoid food, the activity of the animals and their spatial position in the test chamber: for example, active or inactive in the high position or on the supports, or active or inactive on the food [13]. These behaviors are observed, on days of food change. The snails were inactive at the time of observation. They hid at the bottom of the microcosm in a hole of about $3 \mathrm{~cm}$ that they dug in the ground. After one minute, the snails started to be active. In the microcosms in the control and nicosulfuron-treated plots, no food remains were observed (Figure 2(a)). In contrast to the above, a significant amount of decaying feed residue was observed in the microcosms on the glyphosate and 2,4-D treated plots (Figure 2(b)). The greatest amount of feed was observed in the microcosms treated with 2,4-D.

\subsubsection{Effect of 2,4-D, Glyphosate and Nicosulfuron on the Growth of Juvenile Achatina fulica Snails}

Statistical analyses at this level showed that growth parameters varied with the different types of 2,4-D, glyphosate and nicosulfuron treatments. Snail weight mass, shell length, and shell diameter showed significant differences at the 5\% threshold (Table 1). Compared to controls, 2,4-D, glyphosate and nicosulfuron inhibited snail growth. In order of toxicity, our results show that nicosulfuron is less toxic than glyphosate, which is almost equal in toxicity to 2,4-D. 


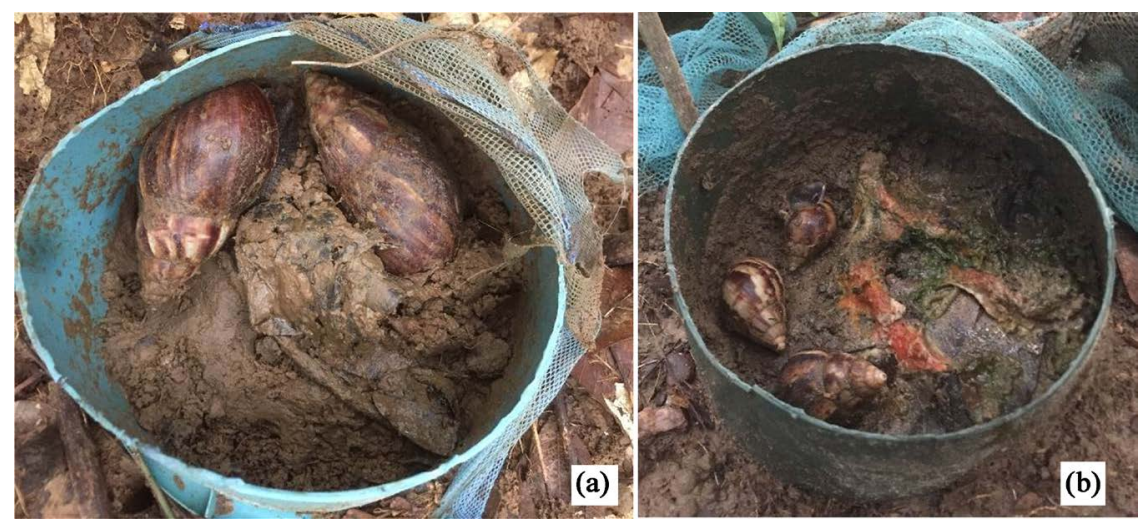

Figure 2. (a) No food remains in the microcosm; (b) Decaying food in the microcosm treated with 2,4-D.

Table 1. Growth parameters (mean \pm standard deviation) of Achatina fulica snails according to herbicide treatments. Values on the same line with the same letter are statistically identical at the 5\% threshold according to Turkey's HSD test. F: Fisher's values; p: Probability.

\begin{tabular}{cccccccc}
\hline \multirow{2}{*}{$\begin{array}{c}\text { Growth } \\
\text { parameters }\end{array}$} & \multicolumn{3}{c}{ Treatments } & & \multicolumn{2}{c}{ Statistics } \\
\cline { 2 - 4 } \cline { 7 - 8 } & 2,4-D & Glyphosate & Nicosulfuron & & F & p \\
\hline Length $(\mathrm{cm})$ & $0.057 \pm 0.06^{\mathrm{b}}$ & $0.185 \pm 0.12^{\mathrm{a}}$ & $0.214 \pm 0.12^{\mathrm{a}}$ & $0.535 \pm 0.14^{\mathrm{c}}$ & 7.83 & $<0.05$ \\
Diameter $(\mathrm{cm})$ & $0.071 \pm 0.09^{\mathrm{a}}$ & $0.15 \pm 0.1^{\mathrm{a} / \mathrm{b}}$ & $0.21 \pm 0.06^{\mathrm{b}}$ & $0.357 \pm 0.08^{\mathrm{c}}$ & 9.29 & $<0.05$ \\
Mass $(\mathrm{g})$ & $0.071 \pm 0.07^{\mathrm{a}}$ & $0.171 \pm 0.11^{\mathrm{a}}$ & $0.342 \pm 0.1^{\mathrm{b}}$ & $0.385 \pm 0.1^{\mathrm{b}}$ & 26.28 & $<0.05$ \\
\hline
\end{tabular}

\subsubsection{Effect of 2,4-D, Glyphosate, and Nicosulfuron Herbicides on the Reproduction of Achatina fulica Snails}

1) Effect on egg production

Egg laying took place 7 days after the establishment of the microcosms on the test and control plots. Moreover, the average number of eggs laid per microcosm and per plot was the same.From day 7 to day 14, the number of eggs laid increased significantly, reaching a peak around 200 eggs laid in the control snails. For snails treated with the different herbicides, a significant drop was observed. Oviposition was zero from day 14 to day 42 for snails in plots treated with 2,4-D and glyphosate. In the nicosulfuron-treated plot, egg laying dropped to zero on day 21. Egg laying resumed on day 28 with an average of 150 eggs per microcosm and decreased slightly on day 35 before dropping sharply on day 42 with an average of 20 eggs. In the control snail plot, from day 14 onwards, egg laying began to decline progressively on days $21,28,35$ and 42 . This egg laying which was around 200 eggs on day 14 went down to around 80 eggs on day 42 . Looking at the control curve, we can see that the egg laying starts on day 7, reaches the peak on day 14 and decreases from day 21 to day 42 (Figure 3).

The mean number of eggs \pm standard deviation laid per pair of snails in the contaminated environment was $41.66 \pm 54.37 ; 48.83 \pm 48.55$ and $62.5 \pm 57.81$ for 2,4-D, glyphosate and nicosulfuron, respectively, compared to $123.16 \pm 31.01$ in the control environment. Statistical analyses revealed a significant difference at 


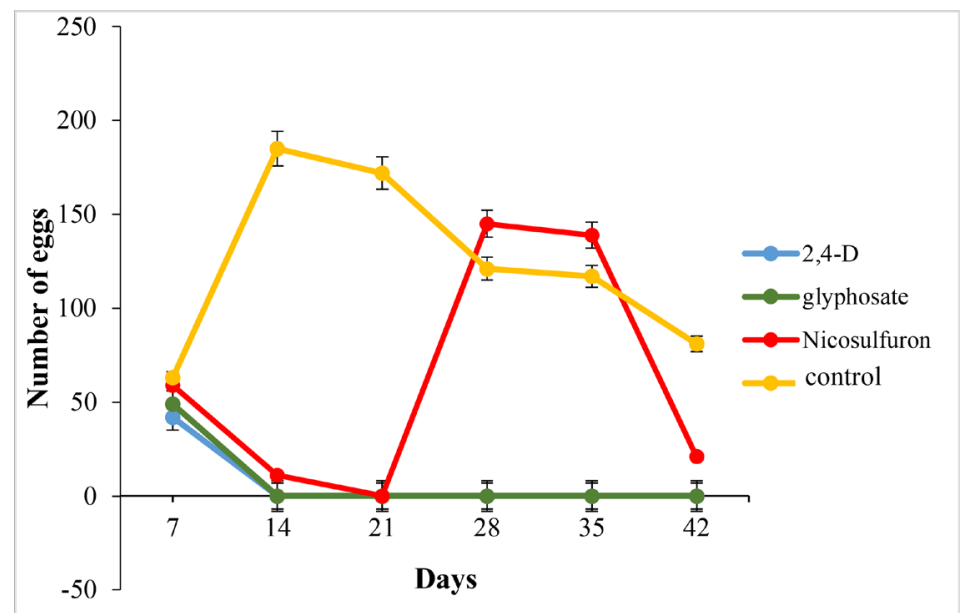

Figure 3. Number of $A$. fulica eggs laid per pair as a function of time.

Table 2. Mean number \pm standard deviation of eggs laid per pair according to treatments. Values on the same line with the same letter are statistically identical at the $5 \%$ threshold according to Turkey's HSD test. F: Fisher's values, p: Probability.

\begin{tabular}{ccccccc}
\hline \multirow{2}{*}{$\begin{array}{c}\text { Parameter } \\
\text { measured }\end{array}$} & \multicolumn{3}{c}{ Treatments } & \multicolumn{2}{c}{ Statistics } \\
\cline { 2 - 7 } & 2,4-D & Glyphosate & Nicosulfuron & Control & F & p \\
\hline $\begin{array}{c}\text { Number of } \\
\text { eggs }\end{array}$ & $41.66 \pm 54.37^{\mathrm{a}}$ & $48.83 \pm 48.55^{\mathrm{a}}$ & $62.5 \pm 57.81^{\mathrm{a}}$ & $123.16 \pm 31.01^{\mathrm{b}}$ & 3.43 & $<0.05$ \\
\hline
\end{tabular}

the $5 \%$ threshold between the different treatments and the number of eggs laid. From the averages obtained, it was found that all herbicide treatments of 2,4-D, glyphosate and nicosulfuron affected egg laying compared to the controls. In terms of toxic effect on oviposition, Tukey's HSD test revealed that 2,4-D, glyphosate and nicosulfuron were equal (Table 2).

\section{2) Effect on hatch rate}

The first hatching of eggs deposited on the 2,4-D and glyphosate-treated plots was observed at 19 days after oviposition while those on the nicosulfuron-treated plot were observed at 17 days after oviposition. The incubation time of eggs deposited on the control plot was 15 days. The average hatching rate \pm standard deviation of eggs from the 2,4-D, glyphosate and nicosulfuron contaminated plots were $5 \% \pm 2 \% ; 20.8 \% \pm 4.2 \%$; and $49.6 \% \pm 11.86 \%$, respectively. In the microcosms on the control plot $82.4 \% \pm 5.17 \%$ of the deposited eggs hatched. The Kruskall Wallis ANOVA test revealed a very highly significant difference between hatching rate and herbicide treatment $(<0.05)$. This result reflects a reduction in hatching rate due to $2,4-\mathrm{D}$, glyphosate, and nicosulfuron. The incubation time of the eggs was different depending on the herbicide product used. Based on the results obtained, 2,4-D was more toxic than glyphosate. Glyphosate was more toxic than nicosulfuron.

\subsection{Discussion}

The phytosanitary treatments of 2,4-D, glyphosate and nicosulfuron carried out 
respectively on each plot induced a growth inhibition of the snails present on these plots. This growth inhibition resulted in a decrease in snail length, shell diameter and mass. This result could be explained by a decrease in consumption rate observed in the microcosms at the time of food change. The decrease in consumption is due to a high concentration of herbicides in the food. Snails have the ability to detect high concentrations of pollutants in their food, which could lead to a decrease in consumption rate [19]. Reference [20] revealed that cadmium can disrupt the function of neurosecretory cells that secrete a growth hormone causing growth arrest. Furthermore, similar observations were made with studies conducted by [19]. They claim that the extreme concentration of lead in the soil, detected by the snails, limits their consumption rate and thus partially inhibits their growth. Other authors have reached the same conclusion in their studies on metal contamination of Helix asperta [21] [22] [23]. Compared to our where growth is inhibited, [24] observed a dose-dependent decrease in growth and survival of snails induced by dimethoate. According to [13], snails exposed by ingestion to thiamethoxam, tefluthrin and their mixtures experienced a reduction in length, shell diameter and weight mass under laboratory conditions. This difference could be due to the conditions under which the tests were performed. Our work was indeed carried out in situ in the natural environment of the snails contrary to theirs which were carried out in laboratory. Chemicals during their application are subject to several transfer mechanisms outside the plot. These matrices receive $97.7 \%$ of pesticides during phytosanitary treatments [10]. Therefore, the amount of herbicides that could reduce snail growth is low.

In addition, it was found in the present study that 2,4-D, glyphosate and nicosulfuron significantly reduce egg laying in Achatina fulica snails. This could be due to a reduction in energy reserves, allocated for reproduction in the storage cells of snail tissues; this reduction is probably caused by the mobilization of these resources for the initiation of detoxification processes. Studies by [25] revealed that the energetic cost of environmental stress results in a decrease in the amount of energy available for reproduction and growth and consequently in a reduction in the fitness of individuals. Our results are in agreement with those of [26]. They showed that chronic exposure of snails to food contaminated with a mixture of metals composed of $\mathrm{Cd}, \mathrm{Cu}, \mathrm{Pb}$ and $\mathrm{Zn}$, delays reproduction. In contrast, those of [12] showed after 240 days of exposure to herbicides no effect on the number of egg laying.

The reduced hatching rate observed in Achatina fulica is probably due to the active substances contained in the herbicides used. According to [27], the snail egg capsule serves as a membrane for gas exchange from the interior of the egg to the environment or vice versa. It acts as an effective barrier against water loss during the incubation period without blocking the air supply. Our results are in agreement with those of [28] who showed that, extracts of Barringtonia racemosa has an increasingly increasing concentration, and significantly affect the hatching of Pomacea canaliculata eggs.

Tests conducted on the effects of herbicides on morphological parameters and 
hatching rate of Achatina fulica eggs revealed increasing toxicity in the following order: nicosulfuron $<$ glyphosate $<2,4$-D. These different responses of snails exposed to these three types of herbicides could be attributed to the different nature and behavior of each herbicide in the environment. These results corroborate those of [29]. Their studies revealed a significant reduction in snail weight mass and shell diameter as a function of treatment type.

\section{Conclusion}

At the end of this study, it was found that herbicide treatments with 2,4-D, glyphosate and nicosulfuron carried out in plantation negatively affected the growth and reproduction of Achatina fulica snails exposed in situ. Treatment of juvenile snails exposed for four weeks to 2,4-D, glyphosate and nicosulfuron in this study revealed a highly significant decrease in physiological parameters such as snail length, shell diameter and mass. On the other hand, observations made on the effects of 2,4-D, glyphosate and nicosulfuron on reproductive parameters such as egg production and hatching rate revealed a highly significant reduction due to the 2,4-D, glyphosate and nicosulfuron herbicides. This reduction is related to the nature of the herbicide. Those based on 2,4-D reduced the number of eggs laid per pair by nearly $66 \%$ and the hatching rate by $77 \%$. Glyphosate reduced the number of eggs laid per pair and hatching rate by about $60 \%$. The herbicide nicosulfuron induced a decrease of about $50 \%$ in the number of eggs laid per pair and a decrease of about $32 \%$ in hatching rate. An increasing toxic effect on hatching rate and physiological parameters was observed in the following order: nicosulfuron $<$ glyphosate $<2,4-\mathrm{D}$. In view of the above, we conclude that the phytosanitary treatments of 2,4-D, glyphosate and nicosulfuron have deleterious effects on the soil. Those based on 2,4-D are more dangerous.

\section{Acknowledgements}

We are especially grateful to the editor and reviewers for their constructive comments on this manuscript.

\section{Conflicts of Interest}

The authors declare no conflicts of interest regarding the publication of this paper.

\section{References}

[1] Bloom, E.D. (2016) Bouleversement démographique. Finances et développement, 11 p.

[2] FAO (1947) Situation mondiale pour 1947 de l'alimentation et de l'agriculture. 16 p.

[3] FAO (1965) Bilan de la deuxième décennie de l'après-guerre. La situation mondiale de l'alimentation et de l'agriculture 1965. 295 p.

[4] Fleischer, G., Andoli, V., Coulibaly, M. and Randolph, T. (1998) Rapport-Analyse Socio-Economique De La Filiere Des Pesticides En Cote d'Ivoire. Projet de Politique des pesticides en collaboration avec la Direction de la Protection des Végétaux et de la Qualité du Ministère de l'Agriculture et des Ressources Animales de Côte d'Ivoire, 
Série de Publication No. 6/F, Abidjan, 112 p.

[5] Traoré, H. and Haggblade, S. (2017) Mise en œuvre des politiques régionales sur les pesticides en Afrique de l'ouest: Rapport de l'étude de cas en Côte d'Ivoire. Feed the Future Innovation Lab for Food Security Policy. 60 p.

[6] Ecobichon, D.J. (2001) Pesticide Use in Developing Countries. Toxicology, 160, 27-33. https://doi.org/10.1016/S0300-483X(00)00452-2

[7] Soro, G., Wahabi, S.A., Adjiri, O.A. and Soro, N. (2019) Risques sanitaires et environnementaux liée à l'usage des produits phytosanitaire dans l'horticulture à azaguié (sud Côte d'Ivoire). Journal Applied Biosciences, 138, 14072-14081. https://doi.org/10.4314/jab.v138i1.7

[8] DPVCQ (2012) Liste des pesticides homologués et autorisés en Côte d'Ivoire au 31 décembre 2012. Direction de la Protection des Végétaux et du Contrôle et de la Qualité. Ministère de l'Agriculture, République de Côte d'Ivoire, 38 p.

[9] Casabé, N., Piola, L., Fuchs, J., Oneto, L.M., Pamparato, L., Basack, S., Giménez, R., Massaro, R., Papa Juan, C. and Kesten, E. (2007) Ecotoxicological Assessment of the Effects of Glyphosate and Chlorpyrifos in an Argentine Soya Field. Journal of Soils and Sediments, 7, 232-239. https://doi.org/10.1065/jss2007.04.224

[10] Tissu, M., Delval, P., Mamarot, J. and Ravanel, P. (2006) Plantes, herbicides et désherbage. Edition: Association de coordination technique agricole, Paris Cedex, $635 \mathrm{p}$.

[11] De Vaufleury, A., Courdassier, M., Pandard, P., Scheifler, R., Lovy, C., Crini, N. and Badot, P.M. (2006) How Terrestrial Snails Can Be Used in Risk Assessment of Soils. Environment Toxicology Chemistry, 25, 797-806. https://doi.org/10.1897/04-560R.1

[12] Druart, C. (2011) Effets des pesticides de la vigne sur le cycle biologique de l'escargot dans divers contextes d'exposition. Thèse de doctorat, Université de Franche-Comté, Besançon, $316 \mathrm{p}$.

[13] Bourbia-ait, H.S. (2013) Evaluation de la toxicité de mixtures de pesticides sur un bioindicateur de la pollution des sols Helix aspersa. Thèse de doctorat, Universite Badji Mokhtar, Annaba, 110 p.

[14] Djatita, O. (2019) Evaluation des effets de l'herbicide Cossack(od) sur les paramètres physiologiques de l'escargot Helix aspersa. Mémoire de master, Université Mohamed El Bachir El Ibrahimi, Bordj Bou Arreridj, 38 p.

[15] Boileau, E. (2015) Ecotoxicologie et impacts sanitaires des pesticides en réponses à l'augmentation des ravageurs amenés par les changements climatiques: Portrait, perspectives et recommandations. Mémoire de maîtrise, université Sherbrooke, Québec, $118 \mathrm{p}$.

[16] N’guessan, K.A., Diarrassouba, N., Koné, B., Alui, K.A. and Yao, K.A. (2015) Caractérisation morpho-pédologique et contraintes au développement de Lippia multiflora sur deux sols tropicaux de Côte d'Ivoire. Journal of Animal and Plant Sciences, 24, 3814-3828.

[17] ISO 15952 (2006) Qualité du sol. Effets des polluants vis-à-vis des escargots juvéniles (Helicidae). Détermination des effets sur la croissance par contamination du sol. https://www.iso.org

[18] OECD (2016) Ligne directrice de l'OCDE $n^{\circ} 243$ pour les essais de produits chimiques. Essai de reproduction chez Lymnaea stagnalis. $31 \mathrm{p}$.

https://doi.org/10.1787/9789264264342-fr

[19] Viard, B., Maul, A. and Pihan, J.-C. (2004) Standard Use Conditions of Terrestrial Gastropods in Active Biomonitoring of Soil Contamination. Journal of Environmen- 
tal Monitoring, 6, 103-107. https://doi.org/10.1039/b307484f

[20] Gomot, A., Gomot, L., Marchand, C.-R., Colard, C. and Bride, J. (1992) Immunocytochemical Localization of Insulin-Related Peptide(s) in the Central Nervous System of Snail Helix aspersa Müller: Involvement in Growth Control. Cellular and Molecular Neurobiology, 12, 21-32. https://doi.org/10.1007/BF00711636

[21] Simkiss, K. and Watkins, B. (1990) The Influence of Gut Microorganisms on Zinc Uptake in Helix aspersa. Environmental Pollution, 66, 263-271. https://doi.org/10.1016/0269-7491(90)90006-X

[22] Swaileh, K.M. and Ezzughayyar, A. (2000) Effects of Dietary Cd and Cu on Feeding and Growth Rates of the Land Snail Helix engaddensis. Ecotoxicology and Environmental Safety, 47, 253-260. https://doi.org/10.1006/eesa.2000.1961

[23] Swaileh, K., Hussein, R. and Halaweh, N. (2002) Metal Accumulation from Contaminated Food and Its Effect on Growth of Juvenile Landsnails Helix engaddensis. Journal of Environmental Science and Health, Part B, 37, 151-159. https://doi.org/10.1081/PFC-120002987

[24] Coeurdassier, M., Saint-Denis, M., Gomot de Vaufleury, A., Ribera, D. and Badot, P.M. (2001) The Garden Snail (Helix aspersa) as a Bioindicator of Organophosphorus Exposure: Effects of Dimethoate on Survival, Growth, and Acetylcholinesterase Activity. Environmental and Chemistry, 20, 1951-1957. https://doi.org/10.1002/etc.5620200913

[25] Lawrence, A.J., Arukwe, A., Moore, M., Sayer, M. and Thain, J. (2003) Molecular/Cellular Processes and the Physiological Response to Pollution. In: Effects of Pollution on Fish, Molecular Effects and Population Responses, Blackwell Science, Oxford, 83-133. https://doi.org/10.1002/9780470999691.ch3

[26] Laskowski, R. and Hopkin, S.P. (1996) Effect of $\mathrm{Zn}, \mathrm{Cu}, \mathrm{Pb}$, and $\mathrm{Cd}$ on Fitness in Snails (Helix aspersa). Ecotoxicology and Environmental Safety, 34, 59-69. https://doi.org/10.1006/eesa.1996.0045

[27] Turner, R.L. (1998) Effects of Submergence on Embryonic Survival and Development Rate of the Florida Apple Snail, Pomacea paludosa: Implications for Egg Predation and Marsh Management. Florida Scientist, 61, 118-129.

[28] Musri, M., Sofia, K., Sofyatuddin, K., Rahmat, R. and Fina, A. (2013) A Preliminary Study on the Anti Hatching of Freshwater Golden Apple Snail Pomacea canaliculata (Gastropoda: Ampullariidae) Eggs, from Barringtonia racemosa (Magnoliopsida Lecythidaceae) Seeds Extract. International Journal of the Bioflux Society, 6, 394-397.

[29] Schuytema, G.S., Nebeker, A.V. and Griffis, W.L. (1994) Effects of Dietary Exposure to Forest Pesticides on the Brown Garden Snail Helix aspersa Muller. Archives of Environmental Contamination and Toxicology, 26, 23-28.

https://doi.org/10.1007/BF00212789 